\title{
The Degree of Secondary Public School Principals' Application of the Knowledge Management Strategies at the Directorate of Education for Zarqa Area: Teachers' Perspective
}

\author{
Yaser Ali Elayyan Abdalaal \\ Jordanian Ministry of Education
}

\begin{abstract}
The aim of this study is to explore the degree of secondary public school principals' application of the knowledge management strategies at the directorate of education for Zarqa area from teachers' perspective. In order to achieve the objectives of the study, the study population consisted of 1263 male and female teachers for the academic year 2019/2020.The study sample consisted of 193 teachers. To achieve the objectives of the study and answer its questions, the researcher prepared a 30-item questionnaire.The researcher explained the results using the descriptive analytical method. The researcher used arithmetic means, standard deviations and (T) tests to determine the significance of differences according to study variables. The results showed that the degree of secondary public school principals' application of the knowledge management strategies at the directorate of education for Zarqa area from teachers' perspective was within the high grade. The results also showed that there were statistically significant differences at the level of 0.05 and less due to the difference of gender for females. The results also showed that there were no statistically significant differences at the level of 0.05 and below due to educational qualification and experience.In the light of the previous results, the researcher recommended increasing the training workshops for school principals and staff to make knowledge management successful, benefit from it in the educational field, work on the application of the strategy of knowledge management as received from the Ministry of Education and train all concerned on its items and contents.
\end{abstract}

Keywords: Knowledge Management Strategy, School Principal, Public High Schools.

DOI: $10.7176 / \mathrm{JEP} / 11-8-07$

Publication date:March $31^{\text {st }} 2020$

\section{Introduction}

The current era in which we live is called the era of knowledge and the age of technology. That is that knowledge is the basis and capital that exceeds its importance and value over the rest of the secondary resources. The decades and past years that we are witnessing today from a modern and advanced knowledge and technology revolution, which led to changes and transformations in the working environments of organizations, whether commercial or industrial, and as recently as we can say, that educational organizations or institutions such as schools, universities and institutes And others have had a plentiful share of these transformations towards the era of knowledge and globalization, or what is known as the new world order, and when talking about these educational institutions it becomes clear that they are facing a strong current of change at the level of the educational system of students, curricula, and school and educational administration as a whole. Schools today It is no longer like schools of the past to receive information and indoctrination operations; rather, it has become active institutions in society through the responsibilities it performs towards students first and who are essential in its existence, and towards the surrounding community as an active and participatory interactive relationship, as this sector attracted the attention of many researchers $\mathrm{N}$ in various countries, for its important role in increasing production and the creation of knowledge and build and activate the process of progress in all walks of life. Many scholars have unanimously agreed that knowledge management is the process of discovering, developing, presenting and assimilating knowledge inside and outside the school through a process of sound management to meet the current and future needs of such institutions. It can be said that knowledge management has become one of the most prevalent entrances at the present time, and with the development of the information and communication revolution made us seriously think about applying knowledge management to exploit information technology as the world is witnessing an unprecedented shift in the field of knowledge and information, which needs to provide qualified human elements that can It contributes to attracting and harnessing it to serve the societies. Therefore, it is imperative that societies support, develop and develop the human cadres in order to enable them to keep abreast of these developments and to exploit and use them in the highest possible efficiency (Falah, 2011).

Knowledge management in our contemporary world is considered one of the most important modern ideas that have an effective impact on the success of the work of institutions and organizations, as a whole based on what is called intellectual capital, in knowledge management by investing available knowledge, and generating ideas that will bring about the required progress, as well as the matter By creating an environment conducive to cognitive creativity and sharing available information and knowledge through the presence of an insight from the institutions 'administrations that their institutions and their employees become a source of knowledge production, 
and this has turned into an institutional culture within the mission and vision that underpins it (Awwad, 2018).

The researcher indicates here that knowledge management in educational institutions came only as a result of interest in the human element (teacher and student) and work to develop and invest in it in a manner that stimulates creativity and innovation in various fields and by virtue of the fact that schools are the ones that create generations that will be essential pillars and pillars in building civilized and advanced societies That is, they are partners in accomplishing them and their homeland at a time when everyone is competing towards achieving the best in all countries, institutions and individuals. The definitions and concepts related to the term knowledge management have multiplied and varied, and the researcher mentioned some of these similar and similar definitions.

Wiig(2013) defined knowledge management as a set of well-defined, well-defined approaches and processes aimed at discovering the functions of knowledge, both positive and negative, in various types of operations, managing them, identifying new products or strategies, and strengthening human resource management. Yassine (2017) defines it as an integrated and interconnected system of skills, experiences, and values with technologies and networks for dealing with data, information, and theories to additional values, and for creative behaviors to perpetuate excellence, excellence, and goal achievement. "Manuel defined them (Manuel, 2008) It is a way for organizations to improve the process of collecting knowledge, using it, and distributing it to enhance the memory of the organization, developing the method in which it is used inside and outside the organization, and finding appropriate ways to communicate with workers with knowledge sources. The concept of knowledge management is mentioned in the Ministry of Education's strategy (strategic Knowledge Management Authority 2014-2016) is that it is the human environment engineering and operations and organization that helps the ministry to produce knowledge and generate it through its selection, organization, use and dissemination and finally transfer of general information and experiences to the right people at the right time, so that they are included in various administrative activities and employ them in rational decision making, problem solving and planning Awad (2018) has defined the concept of knowledge management as a close system that helps to spread knowledge through individuals or groups within the organization in order to raise the level of performance and work management efficiently and effectively and by using means and Modern facilities available. The researcher notes through the previous definitions that knowledge management in a nutshell is a system for generating knowledge, organizing it and maximizing its use, which benefits the organizations of all kinds and individuals as a whole.

The importance of knowledge management in organizations is illustrated by the following points that Falah pointed out (2011), namely: that knowledge management is a great opportunity for organizations to reduce costs and raise their internal assets to generate new revenue. Knowledge management is an integrative systematic process to coordinate the various activities of an organization to achieve its goals. Knowledge management enhances the organization's ability to maintain and improve organizational performance based on experience and knowledge. Knowledge management allows the organization to define, develop, share and then apply the required knowledge and evaluate it. Knowledge management is a way to encourage the creative capabilities of human resources to create new knowledge. Finally, knowledge management is an effective tool for investing intellectual capital by making access to knowledge an easy, available and possible process. (Rastogi, 2001) summarized the importance of knowledge management in educational institutions by providing opportunities for continuous learning for individuals and fostering innovation, providing opportunities for individuals and participating in dialogue, research and discussion, establishing systems for understanding, disseminating and participating in learning, encouraging workers to develop and participate in a collective vision, and helping individuals, To define the role, requirements and contents of knowledge and its applications to accomplish their work, and to identify leaders who build and support learning models at the individual, team, and organizational levels and their development. The importance of knowledge management in educational institutions, especially in schools, through what was reported by the Ministry of Education as stated in the ministry's strategy (2014) in its ability to achieve the retention of expertise, experiences and skills, knowledge is the key to building the educational institution, which gives the intrinsic value to it and also helps in Reducing communication gaps between experts and new employees in the educational institution, and improving the level of the educational institution, in addition to developing the ability to learn from previous experiences. It can be said that knowledge management processes operate sequentially, and complement each other, as each process depends on the other, and integrates with it and supports them, and these processes are referred to by many studies, including my studies (Ziadat, 2008: 90) and (Mahamid, 2008: 29). Which:

Diagnosis of knowledge: Diagnosis is an important issue in the knowledge management program because its goal is to discover the knowledge of the organization, and to identify the people who carry it, and their locations as well. It locates this knowledge in the rules, and identifies us with the appropriate knowledge to develop solutions to the problem. Knowledge planning: relates to drawing different plans related to knowledge management, supporting the goals of knowledge management, individual and organized activities, and striving to provide the capabilities and capabilities necessary to conduct business efficiently and effectively, providing specialized expert teams, and determining the necessary technological facilities. Knowledge Generation: The process of generating 
knowledge focuses on expanding the knowledge generated by individuals, and then developing it at the group level through dialogue and sharing experience. Storing knowledge: The process of storing knowledge indicates the importance of organizational memory, because organizations face a great danger as a result of losing a lot of knowledge those individuals who leave it for one reason or another. Therefore, storing knowledge and keeping it very important for the continuation of organizations, achieving their goals, and developing their services. Distribution of knowledge: The distribution of knowledge refers to ensuring that the appropriate knowledge reaches the person who is searching for it at the appropriate time, and that it reaches the largest number of people working in the organization, and there must be means to transfer this knowledge from one level to another in order to ensure the arrival of knowledge without any obstacle, and that Through education, training programs and systems based on automated knowledge. Application of knowledge: This leads to an improvement in the level of deepening knowledge. There is no doubt that this stage is the most important. There is no importance for knowledge to acquire, generate, store and develop if it is not accompanied directly by the application processes on the ground.

Hence, the educational system stands out as the most important engine for bringing about an immediate change and a real revolution in the pattern of thinking, starting from the family and the school and ending with research centers and universities so that the knowledge and means that support their achievement, preservation, analysis and employment become the basis of the educational system (Al-Malkawi, 2007).

Administrative work in the current era is based on advanced and advanced knowledge, which requires management of a special kind represented in knowledge management, which has become an urgent necessity in all institutions of different roles, tasks and levels, due to the widespread knowledge, and knowledge of this knowledge, preservation, retrieval and dissemination, all This requires management for it, and to ensure the completion of this management it is necessary to be guided by some administrative models in this field, so the need emerged to define a model for universities and shift them from the level of dealing with information to the level of knowledge building to the ability to apply, in the sense of lack of craving When dealing with and preserving information, knowledge management is activities directed to creating knowledge through teaching, learning and re-education within the required change, and in the planned manner that enhances the competitive advantage in spreading and using knowledge, with the aim of improving quality and increasing profitability and continuous development.

In this regard, Gibran (2015) conducted a study aimed at identifying the degree of application of knowledge management processes at Sultan Qaboos University in the Sultanate of Oman from the viewpoint of its faculty members, and the study found that there were no statistically significant differences between the averages of the responses of faculty members in operations Knowledge management at Sultan Qaboos University is attributable to the effect of gender, academic, and sexual variables, while statistically significant differences were attributed to the effect of the variables of years of experience and college. Al-Zahir (2015) conducted a study aimed at building a proposed pedagogical guide for knowledge management in UNRWA schools in Jordan. The results of the study showed that the reality of applying knowledge management in UNRWA schools in Jordan from the viewpoint of school principals, in general, came with a medium degree. The results also showed that there are statistically significant differences attributable to the variable of years of experience on the axes of (diagnosing knowledge, generating knowledge, organizing knowledge, storing and sustaining knowledge, retrieving knowledge), while the results showed that there were no statistically significant differences attributable to this variable on the axis (sharing in knowledge The results also showed that there were no statistically significant differences attributable to the study variables (gender, educational qualification, educational region) on all axes of applying knowledge management and applying total knowledge management. Abdel-Hadi (2018) conducted a study aimed at studying the effect of knowledge utilization in crisis management among the principals of government basic schools in the capital, Amman, and the study concluded with several results, including the existence of an effect to employ knowledge of their combined variables in crisis management, and the results also showed an impact among all who share knowledge And the application of knowledge to crisis management, and the absence of an effect between knowledge generation and crisis management. The results also indicated that there are no differences in the areas of knowledge utilization in crisis management facing principals of primary schools in government schools in the capital Amman due to gender or experience. The study recommended the necessity of adopting knowledge management strategies and applying them properly in all public and private schools.

Based on the foregoing, this study comes in the search for the degree of application of principals of public secondary schools to knowledge management strategies in the Directorate of Education for the Zarqa Region from the viewpoint of teachers.

\section{The study Problem}

Today, many organizations face many challenges as a result of rapid developments and changes, which has become a concern among these organizations that their continuity is mortgaged and linked to their accompaniment and response to such global changes, to achieve profits, benefits, etc., and therefore knowledge management as a 
modern and modern management approach was a method and method adopted by many organizations Different activities by focusing on the intellectual capital of employees and its development, and through strategies of knowledge management to achieve its desired goals. When talking about organizations, it can be said that educational institutions live a time of changes and changes in their approaches and main principles emanating from the general goals of education in countries, and the viewer and viewer see that educational institutions, especially schools, are suffering in many countries from their inability to carry out their tasks and duties for many reasons, which negatively affected On its educational outputs from students, which is essentially the focus of the educational process and is the real capital that exceeds the importance of the rest of the other resources. Therefore, the countries have become alert and tend to have their schools be schools of knowledge, creativity and excellence that take care of their students. For them to be the builders of tomorrow for their future and the future of their country, and since knowledge management has achieved successes in various industrial, commercial and administrative sectors, it was obligatory for those in the education sector to employ this approach, strategies and operations based on the human element as a main axis in the overall renaissance to achieve better learning opportunities for students and care Teachers and beneficiaries of the educational process as a whole. Specifically, the current study sought to answer the following questions:

1. What is the degree of the application of principals of public secondary schools to knowledge management strategies in the Directorate of Education for the First Zarqa Region?

2. Are there statistically significant differences in the degree to which government secondary school principals have applied knowledge management strategies in the Directorate of Education for the First Zarqa Region due to gender, educational qualification, and experience?

\section{Objectives of the study}

The current study aims to know the degree of application of the directors of public secondary schools in the Directorate of Education for the first Zarqa region to knowledge management strategies and the relationship of this to some variables.

\section{The importance of studying}

The importance of this study comes through the role of knowledge management strategies and their impact on the school educational environment from teachers and students, and its importance also comes through its results that may benefit decision-makers and stakeholders in the Ministry of Education in building new strategies for knowledge management, and the researcher hopes that this study will be a theoretical background for studies Suffix.

\section{Terminology of study}

1. Knowledge Management Strategies: It is the future vision of what institutions and organizations will be in the future (Al-Hazani, 2013). Procedurally defined as the practices and procedures that must be applied in educational institutions and its positive impact in improving the learning environment.

2. The principal of the school: He is defined procedurally as the person who is scientifically and behaviorally qualified and who possesses many leadership and administrative qualities and skills that enable him to lead the school in a manner that achieves the goals and objectives of the existence of such institutions, namely achieving the general goals of education and creating a good generation who believes in its role in building its homeland and service His nation.

3. Public secondary schools: They are defined procedurally as educational institutions under the supervision of the Ministry of Education, which includes the secondary school level (first, secondary, and secondary secondary) with its comprehensive academic and vocational branches.

4. The Directorate of Education for the First Zarqa Region: It is procedurally defined as one of the directorates of education affiliated to the Ministry of Education in the Hashemite Kingdom of Jordan and it is located in the governorates of Al-Wasat (Zarqa Governorate), and it includes many public and private schools.

\section{The limits of the study}

Spatial limits: Secondary government schools in Zarqa Governorate.

Time limits: school year 2019/2020.

Study methodology: An analytical descriptive approach was used to suit the nature of the study.

Study Population: The study population consisted of all 1263 male and female teachers in government secondary schools in Zarqa Governorate.

Study Personnel: The study sample consisted of (193) male and female teachers. 


\section{Study tool}

The researcher in developing a questionnaire to achieve the objectives of the study relying on previous literature such as (Al Hallaq, 2014), (Al-Qahtani, 2013), (Al-Lehyani, 2010). It was distributed to the members of the study sample to collect data and analyze it through the SPSS program, and a five-Likert scale was adopted (very high, high, medium, low, and very low), to measure the response of the study sample individuals to the questionnaire designed for this purpose, and was given (very low) Number (1), (low), number (2), (medium), number (3), (high), number (4), (very high), number (5).

\subsection{Validity and reliability of the study tool}

The validity and validity of the study tool was verified by presenting it in its initial form to (12) arbitrators with specialists from university professors in the fields of educational management, curricula, teaching, measurement and evaluation, to determine the appropriateness of the paragraphs contained in the study tool, the extent of the integrity of the language, and the extent of belonging to the paragraphs, as well as He mentioned any proposed amendments and proposed any paragraphs they deemed necessary and deleted the unnecessary, and after requestioning the proposed amendments made by the competent university professors of the arbitrators were made in their recommendations and the amendments were to reshape the linguistic wording of some paragraphs, and delete some paragraphs but Because it is not appropriate, and in light of the amendments, the questionnaire consisted of (30) items in its final form.

To confirm the stability of the questionnaire, the internal consistency coefficient of the paragraphs was calculated using the Cronbach Alpha $\alpha$ equation and the constant coefficient of the questionnaire was (0.90), and these values were considered acceptable for the purposes of the study.

\subsection{Study variables}

First: independent variables:

Gender has two levels: male (teacher) and female (teacher.(

-The educational qualification has 3 levels: Bachelor, Higher Diploma, Master or more.

-Experience and has 3 levels: less than 5 years, and from 5-10 years, more than 10 years.

Second: dependent variables:

The degree to which high school principals apply knowledge management strategies in the Directorate of Education for the Zarqa Region from the teachers' point of view.

\subsection{Correct the answers}

The degree of application of secondary school principals to knowledge management strategies in the Directorate of Education for the Zarqa Region from the teachers point of view has been classified into five levels (very high, high, medium, low, and very low), according to the averages of the sample responses for each paragraph as follows: Category Length $=($ Maximum Substitutes - Minimum Substitutes $) /$ Number of levels

$$
\text { Category length }=(5-1) / 3=1.33
$$

$$
2.33=1.33+1
$$

Thus, the limits of the three levels are as follows:

The mean was less than 2.33 possession low.

Count the mean of $2.34-3.66$ average possession.

Count the arithmetic mean that is more than 3.67 high possession range.

\section{View and discuss the results}

Below are the results related to each study question and the results were as follows:

First question: What is the degree of the application of the principals of public secondary schools to knowledge management strategies in the Directorate of Education for the Zarqa Region from the viewpoint of teachers?

To answer the question, arithmetic averages and standard deviations were calculated and the rank and degree of implementation of secondary government school principals for knowledge management strategies in the Directorate of Education for the Zarqa Region were determined from the teachers point of view, and Table 1 shows that: 
Table 1: Mathematical Averages, Standard Deviations, and Rank of respondents 'responses about the degree to which secondary school school principals have applied knowledge management strategies in the Directorate of Education for Zarqa from the teachers' point of view, sorted in descending order according to the arithmetic mean.

\begin{tabular}{|c|c|c|c|c|c|}
\hline number & Statement & $\begin{array}{l}\text { Arithmetic } \\
\text { mean }\end{array}$ & $\begin{array}{l}\text { standard } \\
\text { deviation }\end{array}$ & $\begin{array}{l}\text { Degree of } \\
\text { commitment }\end{array}$ & arranging \\
\hline 12 & $\begin{array}{l}\text { The principal evaluates the human } \\
\text { resources at the school to benefit from } \\
\text { their experiences. }\end{array}$ & 4.20 & 3.088 & High & 1 \\
\hline 6 & $\begin{array}{l}\text { The principal is well planning school } \\
\text { activities as a form of knowledge } \\
\text { management. }\end{array}$ & 4.19 & 0.835 & High & 2 \\
\hline 9 & $\begin{array}{l}\text { The principal seeks to take advantage } \\
\text { of the tacit knowledge (experiences, } \\
\text { ideas, values). }\end{array}$ & 4.13 & 0.855 & High & 3 \\
\hline 7 & $\begin{array}{l}\text { The director is interested in the library } \\
\text { and using the information network as } \\
\text { a form of knowledge management. }\end{array}$ & 4.10 & 3.337 & High & 4 \\
\hline 5 & $\begin{array}{l}\text { The principal knows the types of } \\
\text { knowledge and information available } \\
\text { at the school. }\end{array}$ & 4.09 & 0.879 & High & 5 \\
\hline 30 & $\begin{array}{l}\text { The principal informs students about } \\
\text { the dates of scientific and cultural } \\
\text { competitions from the beginning of } \\
\text { the school year. }\end{array}$ & 4.08 & 0.909 & High & 6 \\
\hline 21 & $\begin{array}{l}\text { The director selects the appropriate } \\
\text { teachers to supervise the types of } \\
\text { activities, knowledge and } \\
\text { information, and by specialization. }\end{array}$ & 4.07 & 0.800 & High & 7 \\
\hline 18 & $\begin{array}{l}\text { The manager invests in interaction } \\
\text { with community members to benefit } \\
\text { from their cognitive expertise. }\end{array}$ & 4.05 & 0.926 & High & 8 \\
\hline 29 & $\begin{array}{l}\text { The manager communicates with } \\
\text { employees and shares their opinions } \\
\text { to make decisions regarding } \\
\text { knowledge. }\end{array}$ & 4.03 & 0.915 & High & 9 \\
\hline 1 & $\begin{array}{l}\text { The headmaster encourages clearly } \\
\text { communicating the term knowledge } \\
\text { management. }\end{array}$ & 4.02 & 0.810 & High & 10 \\
\hline 8 & $\begin{array}{l}\text { The manager works to spread } \\
\text { organizational culture to complete } \\
\text { knowledge management success. }\end{array}$ & 3.96 & 0.906 & High & 11 \\
\hline 4 & $\begin{array}{l}\text { The manager is interested in } \\
\text { information technology that } \\
\text { contributes to the development of } \\
\text { knowledge management }\end{array}$ & 3.96 & 0.859 & High & 11 \\
\hline 17 & $\begin{array}{l}\text { The principal encourages students to } \\
\text { brainstorm in a democratic } \\
\text { environment. }\end{array}$ & 3.94 & 0.975 & High & 12 \\
\hline 3 & $\begin{array}{l}\text { The manager is interested in } \\
\text { technological development as a form } \\
\text { of knowledge management. }\end{array}$ & 3.94 & 0.939 & High & 12 \\
\hline 23 & $\begin{array}{l}\text { The director implements the cognitive } \\
\text { and scientific plans and cognitive } \\
\text { activity programs that were } \\
\text { established at the beginning of the } \\
\text { year. }\end{array}$ & 3.94 & 0.899 & High & 12 \\
\hline
\end{tabular}




\begin{tabular}{|c|c|c|c|c|c|}
\hline number & Statement & $\begin{array}{l}\text { Arithmetic } \\
\text { mean }\end{array}$ & $\begin{array}{l}\text { standard } \\
\text { deviation }\end{array}$ & $\begin{array}{l}\text { Degree of } \\
\text { commitment }\end{array}$ & arranging \\
\hline 25 & $\begin{array}{l}\text { The manager develops solutions to } \\
\text { remedy the problems they face while } \\
\text { implementing knowledge plans. }\end{array}$ & 3.91 & 0.891 & High & 13 \\
\hline 14 & $\begin{array}{l}\text { The manager encourages the } \\
\text { utilization of the knowledge acquired } \\
\text { by workers to use it as a basis for } \\
\text { creating new knowledge. }\end{array}$ & 3.91 & 0.858 & High & 13 \\
\hline 28 & $\begin{array}{l}\text { The principal is keen on developing } \\
\text { the teacher professionally and } \\
\text { cognitively to transfer its impact into } \\
\text { the classroom. }\end{array}$ & 3.90 & 0.982 & High & 14 \\
\hline 13 & $\begin{array}{l}\text { The manager encourages informal } \\
\text { meetings between workers to } \\
\text { exchange knowledge. }\end{array}$ & 3.89 & 0.917 & High & 15 \\
\hline 2 & $\begin{array}{l}\text { The Principal views Knowledge } \\
\text { Management as an information } \\
\text { management. }\end{array}$ & 3.88 & 0.879 & High & 16 \\
\hline 27 & $\begin{array}{l}\text { Knowledge management can be used } \\
\text { to find out the job performance of the } \\
\text { school and its teaching staff. }\end{array}$ & 3.84 & 0.963 & High & 17 \\
\hline 11 & $\begin{array}{l}\text { The manager works on developing } \\
\text { creative thinking for workers to } \\
\text { exchange knowledge. }\end{array}$ & 3.83 & 0.959 & High & 18 \\
\hline 10 & $\begin{array}{l}\text { The principal prepares and } \\
\text { implements training programs to } \\
\text { develop the cognitive skills of school } \\
\text { personnel. }\end{array}$ & 3.83 & 0.932 & High & 18 \\
\hline 15 & $\begin{array}{l}\text { The principal provides the financial } \\
\text { means to support the freedom of } \\
\text { scientific research for school } \\
\text { personnel. }\end{array}$ & 3.81 & 1.025 & High & 19 \\
\hline 26 & $\begin{array}{l}\text { The manager discusses the actual } \\
\text { achievement of knowledge goals. }\end{array}$ & 3.81 & 0.922 & High & 19 \\
\hline 19 & $\begin{array}{l}\text { The manager works to activate an } \\
\text { electronic system that serves the } \\
\text { process of organizing knowledge. }\end{array}$ & 3.81 & 0.899 & High & 19 \\
\hline 16 & $\begin{array}{l}\text { The manager develops an appropriate } \\
\text { budget to support knowledge } \\
\text { management projects. }\end{array}$ & 3.78 & 1.009 & High & 20 \\
\hline 20 & $\begin{array}{l}\text { The manager develops a plan to } \\
\text { anticipate changes in cognitive } \\
\text { content. }\end{array}$ & 3.78 & 0.858 & High & 20 \\
\hline 24 & $\begin{array}{l}\text { The director creates promotional } \\
\text { awards for groups that excel } \\
\text { scientifically, culturally and } \\
\text { cognitively. }\end{array}$ & 3.70 & 1.062 & High & 21 \\
\hline \multirow[t]{2}{*}{22} & $\begin{array}{l}\text { The principal holds educational } \\
\text { training sessions for teachers to keep } \\
\text { abreast of knowledge developments. }\end{array}$ & 3.62 & 0.951 & Medium & 22 \\
\hline & Total & 3.93 & 1.067 & \multicolumn{2}{|l|}{ High } \\
\hline
\end{tabular}

The results presented in Table (1) indicate that the responses of the sample members to the questionnaire expressions had a total arithmetic high of (3.93) and a standard deviation of (1.067), and the arithmetic averages ranged (4.22 - 3.62), and came in first rank paragraph (12), Which states, "The principal assesses the human resources present in the school to benefit from their experiences" with an mean (4.20) and a standard deviation (3.088), and in the second rank comes paragraph (6), which states "The director plans well for school activities as a form of knowledge management With an average mean (4.19) and a standard deviation (0.835), it came in the 
penultimate rank, paragraph (24), which states "J The director set promotional awards for groups that excel scientifically, culturally and cognitively "with an arithmetic average (3.70), and a standard deviation (1.062), and came in the last rank in paragraph (22), which states that" the director holds educational training courses for teachers to keep abreast of cognitive developments "with an arithmetic mean (3.62) ), And standard deviation (0.951). This is due to the fact that the Ministry of Education, based on the application of the knowledge management strategy in schools and the Ministry as a whole, is keen to ensure that the educational process becomes more mature and open to the world in which we live and is better able to adapt to its changes. The new legislation to select school principals emphasizes several criteria that a principal must The school has to enjoy it so that the educational and school environment becomes compatible with the requirements of the knowledge economy. Likewise, the training courses for principals in schools such as the (ICDL, INTEL) course provided by the ministry and other courses have made school principals people who employ everything new in Pain and knowledge to serve their schools and their students in each location, the application of this knowledge management and the need for ownership by managers would improve the educational process and the business climate for teachers as well as to take administrative Alaqraarat. This result was consistent with the study of Al-Qahtani (2013), the study of AlLehayani (2010), the study of Badr (2010), and a study (Feliciano, 2007).

Results related to the second question: What is the degree of application of the principals of public secondary schools to knowledge management strategies in the Directorate of Education for the Zarqa Region from the teachers' point of view due to the gender variable, educational qualification, experience?

This question was answered as follows:

First: the gender variable:

The Independent Sample T-test was used to calculate the value of $(\mathrm{T})$ for the responses of the sample members on the different fields of study, and Table (2) shows that:

Table 2: (T- test) to indicate the significance of the differences between the averages of the sample

members regarding the degree of the implementation of government secondary school principals to knowledge management strategies according to the gender variable

\begin{tabular}{|c|c|c|c|c|c|c|c|}
\hline \multirow{3}{*}{$\begin{array}{ll}\text { The degree } & \text { of applying } \\
\text { knowledge } & \text { management } \\
\text { strategies } & \end{array}$} & Gender & number & $\begin{array}{l}\text { Arithmetic } \\
\text { mean }\end{array}$ & $\begin{array}{l}\text { standard } \\
\text { deviation }\end{array}$ & $\begin{array}{l}\text { Value } \\
\text { of } t\end{array}$ & df & Sig. \\
\hline & Male & 94 & 3.77 & 0.701 & \multirow[t]{2}{*}{3.183} & \multirow[t]{2}{*}{191} & \multirow[t]{2}{*}{.002} \\
\hline & female & 99 & 4.09 & 0.656 & & & \\
\hline
\end{tabular}

The results of the test $(\mathrm{T})$ between the mean scores of the sample individuals about their estimates of the degree of government school principals applying to knowledge management strategies in the Directorate of Education for the Zarqa Region from the teachers point of view according to the gender variable (male, female) mentioned in Table (2) that there are significant differences A statistic attributable to the gender variable in favor of females with regard to the degree of application of secondary school principals to knowledge management strategies in the Directorate of Education for the Zarqa Region from the teachers point of view, where the values of $(\mathrm{T})$ were indicative at the level of statistical significance $(0.05)$.

Second: The qualification variable:

Arithmetic averages and standard deviations were calculated for the degree of the application of principals of public secondary schools to knowledge management strategies in the Directorate of Education for the Zarqa Region from the point of view of teachers, according to the variable of the educational qualification, and Table (3) shows that.

Table 3: Mathematical averages and standard deviations for the degree to which high school principals apply knowledge management strategies, depending on the variable of qualification

\begin{tabular}{|l|l|l|l|l|}
\hline \multirow{3}{*}{$\begin{array}{l}\text { The degree of applying } \\
\text { knowledge } \\
\text { management strategies }\end{array}$} & Qualification & number & $\begin{array}{l}\text { Arithmetic } \\
\text { mean }\end{array}$ & $\begin{array}{l}\text { standard } \\
\text { deviation }\end{array}$ \\
\cline { 2 - 5 } & Bachelor's degree & 154 & 3.96 & $\mathbf{0 . 6 8 9}$ \\
\cline { 2 - 5 } & High diploma & 20 & 4.02 & $\mathbf{0 . 4 9 0}$ \\
\cline { 2 - 5 } & Master and more & 19 & 3.59 & $\mathbf{0 . 8 6 0}$ \\
\cline { 2 - 5 } & Total & 193 & 3.93 & $\mathbf{0 . 6 9 3}$ \\
\hline
\end{tabular}

It is noted from Table (3) that there are apparent differences between the arithmetic averages of the degree of the application of the directors of public secondary schools to knowledge management strategies in the Directorate of Education in the Zarqa Region from the teachers point of view, according to the variable of the educational qualification, as the owners of the qualification (higher diploma) obtained the highest arithmetic average reached (4.02), the holders of the qualification (Bachelor) came second in the mathematical average of (3.96) and finally the arithmetic mean of the qualification (Master or more) came to (3.59), and to determine whether the differences between the averages are statistically significant at the degree of significance $(0.05 \geq \alpha)$ One way ANOVA was applied, and results came out $\mathrm{C}$ Analysis of variance as illustrated in Table 4: 
Table 4: Results of (One Way Anova) test to show the significance of the differences between the averages of the sample members regarding the degree of applying the knowledge management strategy according to the variable of the educational qualification

\begin{tabular}{|c|c|c|c|c|c|c|}
\hline \multirow{4}{*}{$\begin{array}{lr}\text { The degree } & \text { of applying } \\
\text { knowledge } & \text { management } \\
\text { strategies } & \end{array}$} & $\begin{array}{ll}\text { Source } & \text { of } \\
\text { contrast } & \\
\end{array}$ & $\begin{array}{ll}\text { Sum } & \text { of } \\
\text { squares } & \\
\end{array}$ & df & $\begin{array}{l}\text { Average } \\
\text { squares }\end{array}$ & f & Sig. \\
\hline & Between groups & 29.360 & 72 & 0.414 & \multirow[t]{3}{*}{1.043} & \multirow[t]{3}{*}{0.414} \\
\hline & Within groups & 47.967 & 121 & 0.396 & & \\
\hline & Total & 77.326 & 193 & & & \\
\hline
\end{tabular}

From Table (4), the result of the One Way Anova test to compare the average scores of the sample individuals according to the experience variable indicates that there are no statistically significant differences attributable to the variable of the scientific qualification, where the calculated $(F)$ values for these domains were not significant at the level of significance $(0.05)$.

Third: Experience variable:

Arithmetic averages and standard deviations were calculated for the degree of implementation of secondary school principals' strategies for knowledge management strategies in the Directorate of Education for the Zarqa Region from the teachers point of view, according to the variable of experience, and Table (5) shows that.

Table 5: Mathematical averages and standard deviations for the degree to which school principals apply knowledge management strategies, depending on the variable of experience

\begin{tabular}{|l|c|c|c|c|}
\hline \multirow{3}{*}{$\begin{array}{l}\text { The degree of } \\
\text { applying }\end{array}$} & Experience & number & Arithmetic mean & $\begin{array}{c}\text { standard } \\
\text { deviation }\end{array}$ \\
\cline { 2 - 5 } $\begin{array}{l}\text { knowledge } \\
\text { management } \\
\text { strategies }\end{array}$ & Less than 5 years & 36 & 3.89 & 0.681 \\
\cline { 2 - 5 } & $\begin{array}{c}\text { From 5 to 10 } \\
\text { years }\end{array}$ & 52 & 4.00 & 0.651 \\
\cline { 2 - 5 } & $\begin{array}{c}\text { More than 10 } \\
\text { years }\end{array}$ & 105 & 3.91 & 0.719 \\
\cline { 2 - 5 } & Total & 193 & 3.93 & 0.693 \\
\hline
\end{tabular}

It is noted from Table (5) that there are apparent differences between the arithmetic averages of the degree of the application of the schools' administrators to the strategies of knowledge management in the Directorate of Education in the Zarqa Region from the viewpoint of teachers, according to the variable of experience, as the owners of the category (from 5-10 years) got the highest arithmetic mean It reached (4.00), and the owners of the category (more than 10 years) came in the second rank with an average score of (3.91) and finally the mean for the category (less than 5 years) came to (3.89), and to determine whether the differences between the averages are statistically significant at the degree of Indication $(0.05 \geq \alpha)$ One way ANOVA was applied, and the results of the variance analysis were As shown in Table (6):

Table 6: The results of (One Way Anova) test to show the significance of the differences between the averages of the sample members in the degree of school secondary school administrators applying knowledge management strategies, according to the variable of experience

\begin{tabular}{|c|c|c|c|c|c|c|}
\hline \multirow{4}{*}{$\begin{array}{l}\text { The degree of applying } \\
\text { knowledge management } \\
\text { strategies }\end{array}$} & $\begin{array}{c}\begin{array}{c}\text { Source of } \\
\text { contrast }\end{array} \\
\end{array}$ & $\begin{array}{c}\text { Sum of } \\
\text { squares }\end{array}$ & df & $\begin{array}{c}\text { Average } \\
\text { squares }\end{array}$ & f & Sig. \\
\hline & Between groups & 1.050 & 3 & 0.350 & \multirow[t]{3}{*}{0.726} & \multirow[t]{3}{*}{$\mathbf{0 . 5 3 8}$} \\
\hline & Within groups & 91.081 & 190 & 0.482 & & \\
\hline & Total & 92.131 & 193 & & & \\
\hline
\end{tabular}

From Table (6), the result of the One Way Anova test to compare the mean scores of the sample individuals according to the experience variable indicates that there are no statistically significant differences attributed to the experience variable, where the calculated $(\mathrm{P})$ values for these fields were not significant at the level of significance ( 0.05).

9. The researcher recommends the following:

1- Working to increase training workshops for school administrators and workers to make knowledge management successful and benefit from it in the educational field.

2- Making more use of the information and communication revolution in the field of education.

3- Working to implement the knowledge management strategy as it came from the Ministry of Education and training all those involved in its terms and contents.

4- Working to connect schools to each other with electronic networks, because of the importance and exchange of experiences. 
10. References

10.1. English references

- Wig, K (2013).Knowledge Management Foundations Thinking about Thinking, USA: Schema Press.

- Manuel: E. ، 2008، “ The Knowledge Management in SADC Countries” ، The Icafi Journal of Knowledge Management، 6(1): 46-55.

- Rastogi, P.N. (2001). Knowledge management and intellectual capital - the new virtuous reality of competitiveness, Human Systems Management, vol. 19, no. 1, pp. 39-48.

- Fullan‘M، (2002). The role of leadership in promotion of knowledge management in schools : "theory and practice " Teachers and Teaching . 8 (3) 409-419.

- Feliciano، J.L.(2007)،The Success Criteria for Implementing Knowledge Management System in an Organization، Pace University.

- Shaghaei, N \& Turgay, T, (2013). Performance Improvement through Knowledge Management and innovation in Educational Institutions: Teachers Perception. Journal on Business Review. 7 (5) 209-222

- Rawat, Madan Singh (2011)“Knowledge Management Leveraging E-Learning in Universities" Proceedings of the International Conference on e-Learning. 2009, p432-439. P8.

\subsection{Translated Arabic references}

-Bader, Yousra (2010). Developing the Skills of Secondary School Principals in the Gaza Strip Governorates in the Light of the Knowledge Management Concept, (Unpublished Master Thesis), Islamic University, Gaza, Palestine.

-Alhalaq, Rima Ali (2014). The Role of Knowledge Management in Decision Making from the Perspectives of Principals and Teachers in Public High Schools in Damascus, MA Thesis, Damascus University, Syria

-Al-Ziyadat, Mohammad Awwad (2008), Contemporary Trends in Knowledge Management, Amman, Safa Publishing House.

-Saleh, Ali Mohammed Jubran and Mansouri, Ahmed bin Mohammed. 2015. Degree of application of knowledge management processes at Sultan University. Hebron University Journal for Research: Journal of Humanities, Vol. 10, p. 2, 1-27.

-Tashkandi, Zakia (2008). Knowledge management: the importance and extent of application of its operations from the point of view of directors of departments and projects departments in Makkah and Jeddah, (unpublished Master), Umm Al-Qura University, Mecca.

-Al-Zaher, Subhi Ahmad (2014), Educational Guide in the Faculty of Graduate Studies at the University, Faculty of Graduate Studies, University of Jordan, Amman, Jordan.

-Abdulhadi, Samira Wassef (2018). The effect of employing knowledge in crisis management. University of Balqa. For rent apartment in Salt

-Awad, Ahmed (2018). The Effect of Knowledge Management on Innovation in Private Schools in Jordan, Master Thesis, Faculty of Economics and Administrative Sciences, Al-Bayt University, Mafraq: Jordan.

-Falah, Mohammed (2011). The impact of knowledge on organizational creativity, the work of the International Forum for creativity and rehabilitation in modern organizations: the study and analysis of international and international experiences - Faculty of Economic Sciences and Management Sciences - University of Dahlab Blida, Algeria.

-Al-Qahtani, Maryam (1433 e). The reality of the application of knowledge management in the schools of the project of developing the city of Riyadh from the point of view of principals and teachers. (Unpublished Master Thesis), Imam Muhammad bin Saud Islamic University, Riyadh, Saudi Arabia.

-Al-Lehyani, Maryam bint Radhi Mashkhas (2010). Knowledge management in the development of secondary schools for girls.

-Mahamid, Riba (2008). The Role of Knowledge Management in Achieving the Quality of Higher Education, An Applied Study in Private Jordanian Universities, (Unpublished Master Thesis), Middle East University, Amman.

-Malkawi, Ibrahim (2007), the role of knowledge management in risk theory, the seventh international scientific conference entitled: risk management and knowledge economy, the University of Jordan Zaytuna, Amman, Jordan, 16-18 / 18/2007.

-Hazani, Nora (2013). Semantic Web Concept and Structure. Journal of Informatics - Saudi Arabia, p 35, 57 - 67. -Ministry of Education: Knowledge Management Strategy for the years (2014-2016).

-Yassin, Saad (2017). Knowledge Management: Concepts, Systems and Techniques, Oman: Dar Al-Manaaj Publishing and Distribution. 